\title{
A monoclonal antibody derived by inoculation of human umbilical vein endothelial cells is a potential inhibitor of acetylcholine receptor-linked vasorelaxation
}

\author{
Seung Hyo Jung ${ }^{1, \star}$, Yunkyoung Ryu ${ }^{1, \star}$, Donghyen Lee ${ }^{1}$, Seung-Bo Park ${ }^{1}$, Kyung-Jin Lee ${ }^{1}$, \\ Hwan Myung Lee ${ }^{2}$, Junghwan Kim³ ${ }^{3}$ Bokyung Kim ${ }^{1}$ and Kyung Jong Won ${ }^{1}$ \\ ${ }^{1}$ Department of Physiology, School of Medicine, Konkuk University, Gwangjin-gu, Seoul, Korea \\ ${ }^{2}$ Department of Cosmetic Science, College of Life and Health Sciences, Hoseo University, Asan, Korea \\ ${ }^{3}$ Department of Physical Therapy, College of Public Health and Welfare, Yongin University, Yongin, Korea
}

\begin{abstract}
In a previous study, we produced antibodies from rats immunized with human umbilical vein endothelial cells (HUVECs) and determined the vascular function of the monoclonal antibodies. However, unanswered question remains still about their role in vascular function. The current study explored vasoreactivity, in particular, focusing on the vascular contractility of a functional antibody against proteins expressed on the plasma membrane of HUVECs developed in a previous study. Among the antibodies developed, A-7 significantly attenuated endothelium-dependent vasorelaxation in response to acetylcholine ( $\mathrm{ACh}$ ) but not to sodium nitroprusside or histamine. In addition, the A-7 antibody did not affect norepinephrine-stimulated contraction in both endothelium-intact and -denuded aorta. Immunocytochemical and immunoblotting analyses showed that A-7 attenuated ACh-increased expression of ACh receptor on the plasma membrane of HUVECs. These findings suggest that the monoclonal A-7 antibody may act as an inhibitor of endothelium-dependent vasorelaxation, probably in part via downregulation of ACh receptor expression.
\end{abstract}

Key words: Antibody - HUVEC - Membrane protein - Acetylcholine receptor - Vasorelaxation

\section{Introduction}

The normal function of vascular endothelial cells (ECs) is essential for the regulation of vascular contractility and is closely linked to maintenance of blood pressure and blood flow in the body. Vascular ECs along with smooth muscle cells (SMCs) contribute to vascular contractility regulated via vascular contraction and relaxation (Rodrigo and Herbert 2018). ECs produce various vasoactive factors such as vasoconstrictors and vasodilators. Physiological stimuli such as physical forces, circulating hormones, platelet products, and prostaglandins can regulate endothelium-dependent vascular contractility (Khaddaj Mallat et al. 2017). Acetyl-

\footnotetext{
* These two authors contributed equally to the manuscript. Correspondence to: Kyung Jong Won, Department of Physiology, Konkuk University School of Medicine, 120 Neungdong-ro, Gwangjin-gu, Seoul 05029, Korea

E-mail: kjwon@kku.ac.kr
}

choline (ACh) is known to induce endothelium-dependent vasorelaxation (Furchgott 1999). The ACh-induced vasorelaxation is mediated by the activation of muscarinic ACh receptors (mAChRs) (Boulanger et al. 1994). The mAChRs comprise the five subtypes (m1AChR through m5AChR) in the vascular system (Wessler et al. 2003; Zarghooni et al. 2007; Wessler and Kirkpatrick 2008). Among the different subtypes, the $\mathrm{m} 3 \mathrm{AChR}$ is the main receptor mediating ACh-stimulated endothelium-dependent vasorelaxation (Boulanger et al. 1994; Gericke et al. 2011). Nitric oxide (NO) is one of the main EC-derived vasodilators and is induced in response to ACh (Köhler and Milstein 1975; Furchgott 1983; Versari et al. 2009). NO production in ECs is triggered by the activation of NO synthase that converts 1-arginine to 1-citrulline. The NO diffuses into SMC layers and activates guanylate cyclase, which induces the elevation of cyclic guanosine monophosphate to elicit vascular SMC relaxation through multiple mechanisms (Omori and Kotera 2007). These responses suggest that NO plays an essential 
role in the regulation of vascular contractility (Pintérová et al. 2011). Human body is exposed to various external stimuli that change blood flow and blood pressure, which are closely associated with NO (Furchgott 1983). Therefore, identification of new functional proteins linked to NO role in ECs may facilitate the study of vascular dilation, although the interaction between NO function and ECs is reported in vascular cells under physiological and pathophysiological conditions.

Plasma membrane in various cells separates the cell from the external environments. It expresses various functional proteins that respond to extracellular stimuli and play important roles in maintaining normal biological responses (Lee et al. 2009; Volonté and D’Ambrosi 2009). Plasma membrane proteins or membrane-associated proteins act as potential targets for biomarkers, drugs and antibodies (Rucevic 2011). Previous studies reported that a third of all known biomarker candidates are membrane proteins (Polanski and Anderson 2007; Josic et al. 2008). Many investigators have demonstrated that a monoclonal antibody can be strategically used against cell membrane antigens to elucidate the function of isolated proteins (Miraglia 1997; Yin et al. 1997). Moreover, the application of antibodies alone or in combination with other drugs has been of clinical and therapeutic interest (Lee et al. 2018). Antibodies display high specificity toward a defined target antigen, and are therefore, considered as unique therapeutics (Hicklin et al. 2001). Therefore, the identification of new functional molecules may provide basic insight into and understanding of their physiological mechanisms in targeted cells including vascular cells. Our laboratory has developed 22 monoclonal antibodies from rats inoculated with HUVECs (Won et al. 2013). Although these antibodies display functional vascular responses, they may be additional antibodies possessing potential vascular reactivity. In the current study, we sought to identify novel functional molecules expressed on the membranes of HUVECs based on their vascular reactivity, especially, vascular contractility.

\section{Materials and Methods}

\section{Materials}

ACh, norepinephrine (NE), histamine, bovine serum albumin (BSA), and sodium nitroprusside (SNP) were purchased from Sigma-Aldrich (St. Louis, MO, USA). Fetal bovine serum (FBS) was obtained from HyClone Laboratories Inc (Logan, UT, USA). The anti-mAChR and IgG2 $\alpha$ antibodies were purchased from Santa Cruz (Santa Cruz, CA, USA). Alexa 488-conjugated anti-rabbit IgG antibody was ordered from Molecular Probes (Eugene, OR, USA).
Tissue preparation and measurement of isometric contraction

Animal care and all the experiments were conducted in accordance with the Guide for the Care and Use of Laboratory Animals published by the US National Instituetes of Health (NIH publication NO. 85-23, revised 1996) and approved by the Animal Subjects Committee and institutional guidelines of Konkuk University, Korea. Male Sprague-Dawley (SD) rats (7-weeks-old, 180-190 g, $n=10$ ) were purchased from Orient $\mathrm{Bio}$ (Korea). The animals were euthanized using $\mathrm{CO}_{2}$ gas inhalation and bled rapidly by severing the carotid arteries (Won et al. 2013; Raffetto et al. 2019). The thoracic aorta was rapidly and carefully removed and placed in a physiological salt solution (PSS) containing the following composition (in $\mathrm{mM}$ ): $\mathrm{NaCl}$ 136.9; $\mathrm{KCl}$ 5.4; $\mathrm{CaCl}_{2} 1.5 ; \mathrm{MgCl}_{2} 1.0 ; \mathrm{NaHCO}_{3}$ 23.8; EDTA 0.01 . The aorta was cleaned by removing fat and connective tissue, and cut into 2-mm ring segments. In some experiments, the endothelium was removed by gently rubbing the inner surface of the vessel with cotton balls soaked in PSS.

The prepared aortic ring segments were mounted on two L-shape holders, of which one end was attached to a stainlesssteel rod, and the other to a force transducer (FT03; GrassTelefactor Instruments, West Warwick, RI, USA), in $3 \mathrm{ml}$ organ baths containing PSS. Changes in muscle force were isometrically recorded on Grass 79E polygraphs (GrassTelefactor Instruments). After the segments were mounted under resting tension of $10 \mathrm{mN}$, they were equilibrated for $30 \mathrm{~min}$ in an organ bath filled with PSS and sequentially exposed to $70 \mathrm{mM} \mathrm{K}^{+}$and PSS. The high $\mathrm{K}^{+}$solution was prepared by replacing $\mathrm{NaCl}$ with an equimolar amount of $\mathrm{KCl}$. All bath solutions were saturated with a mixture of $95 \%$ $\mathrm{O}_{2}$ and $5 \% \mathrm{CO}_{2}$ at $\mathrm{pH} 7.4$ and $37^{\circ} \mathrm{C}$.

\section{HUVEC culture}

HUVECs were enzymatically isolated from human umbilical cord veins as described previously (Jaffe et al. 1973). The endothelial cells were cultured in gelatin (0.1\%)-coated culture flasks filled with M199 medium (Welgene, Korea) containing 20\% FBS, $100 \mathrm{U} / \mathrm{ml}$ penicillin, $100 \mu \mathrm{g} / \mathrm{ml}$ streptomycin, $3 \mathrm{ng} / \mathrm{ml}$ bFGF, 5 units $/ \mathrm{ml}$ heparin and $250 \mu \mathrm{g} / \mathrm{ml}$ fungizone. The cells were used in passages two to six for each experiment.

\section{A-7 antibody production}

The A-7 monoclonal antibody against HUVECs was produced by injecting HUVECs into 6-week-old SD rats (Orient Bio) as described previously (Won et al. 2013). Briefly, rats were immunized by injecting $3 \times 10^{5}$ HUVECs on days 0 and 7 in both hand footpads. After a second injection, lymphocytes from lymph node were prepared and fused to SP2/0 
myeloma cells. Fused cells were cultured on 96-well plates in Dulbecco's Modified Eagle's medium (DMEM; Welgene, Daegu, Republic of Korea) supplemented with 20\% FBS and incubated at $37^{\circ} \mathrm{C}$ in $5 \% \mathrm{CO}_{2}$. For screening hybridoma cells, culture supernatants were screened on HUVECs using a fluorescence-activated cell analyzer (FACS) Calibur (BD Biosciences, San Jose, CA, USA). Monoclonal antibodies were traced by phycoerythrin (PE)-conjugated mouse antirat immunoglobulin $\mathrm{G}$ antibody (IgG) (BD Pharmingen, San Diego, CA, USA). The experimental monoclonal A-7 antibody was prepared from ascites fluid by purifying protein-A column.

To determine the specific binding ability of A-7 antibody, HUVECs were stained with anti-A-7 antibody and PE-conjugated anti-rat IgG as the secondary antibody. The stained cells were analyzed with a FACS Calibur (BD Biosciences) and the data were collected using only live cells labeled with propidium iodide (PI). The frequencies in quadrant corners are given as percentages of gated cells. The collected data were analyzed using the CELLQUEST software (BD Biosciences).

\section{Immunofluorescence staining}

Expression of AChR in the cultured HUVECs was determined using a standard immunostaining method. Briefly, the cells were cultured on a cover glass coated with poly-dlysine, and fixed with $4 \%$ formaldehyde at $37^{\circ} \mathrm{C}$ for $30 \mathrm{~min}$. After washing in PBS, cells were blocked by incubation with $1 \%$ BSA for 1 hour followed by treatment with primary antibodies and rabbit anti-mAChR (1:100) antibodies at room temperature (RT) for 2 hours. After washing, the secondary Alexa 488-conjugated anti-rabbit IgG antibody was used at a dilution of 1:400 for 1 hour at RT. The immunostained cells were observed by fluorescence microscopy (Axio Observer A1; Carl Zeiss, Jena, Germany). Immunohistochemical staining of images was quantified using MetaMorph imaging software (ver 7.1; Molecular Devices, Downingtown, PA, USA).

\section{Immunoblotting}

The cell lysates were centrifuged at $17,000 \times g$ for $15 \mathrm{~min}$ at $4^{\circ} \mathrm{C}$ and the supernatants were collected as protein samples. Proteins $(35 \mu \mathrm{g} / \mathrm{lane})$ were separated on $8 \%$ SDSpolyacrylamide gel and then transferred electrophoretically to a polyvinylidene fluoride membrane (Millipore, Bedford, MA, USA). The membranes were blocked with PBS containing 5\% BSA, incubated overnight at $4^{\circ} \mathrm{C}$ in the primary antibodies (1:1000 dilution), and subsequently incubated in the peroxidase-conjugated secondary (1:3000 dilution) for 1 hour at RT. The blots were incubated in enhanced chemiluminescence solution (Amersham-Pharmacia, Piscataway, NJ, USA) and the bands were visualized using a Luminescent Image Analyzer LAS-4000 (Fujifilm, Tokyo, Japan). Band intensity was quantified using ImageJ software (NIH, Bethesda, MD, USA).

\section{Statistical analysis}

Data are expressed as the mean \pm SE. All data were analyzed using GraphPad Prism (GraphPad Software, San Diego,

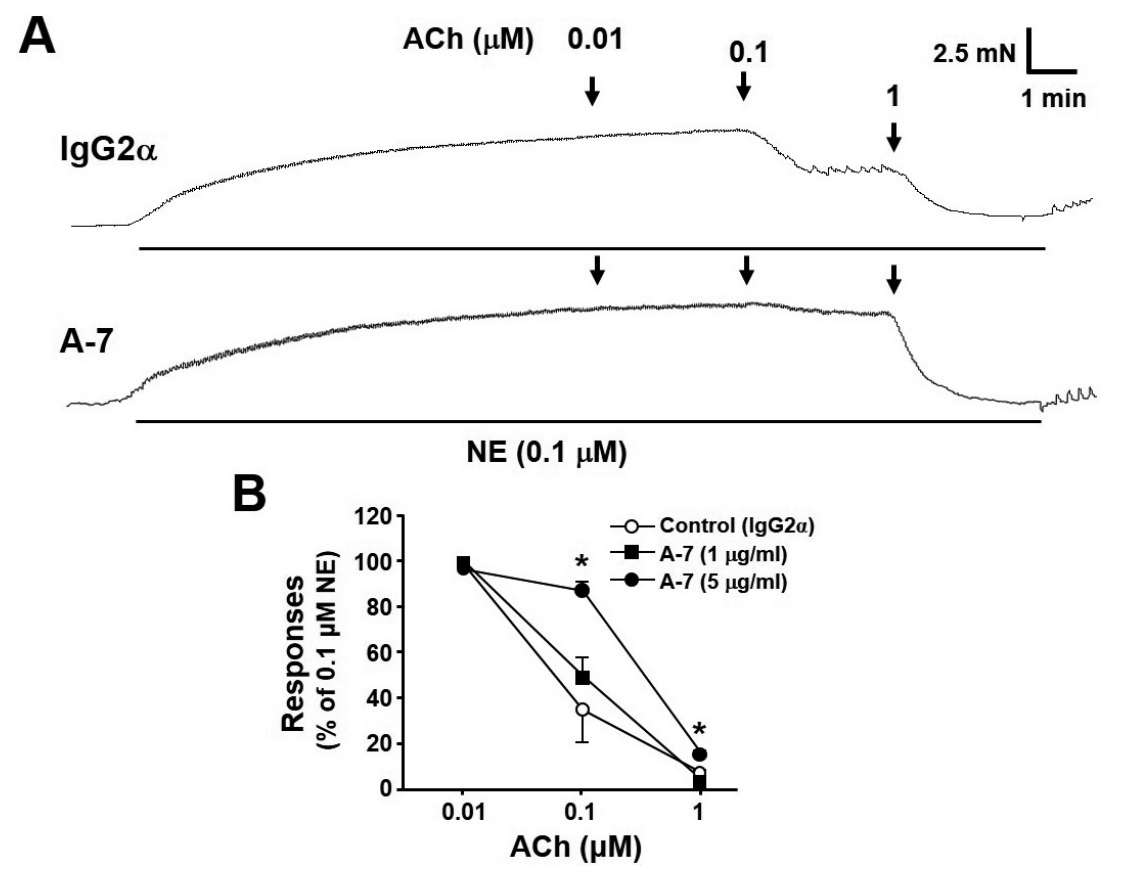

Figure 1. Effects of A-7 antibody on endothelium-dependent vasorelaxation in response to acetylcholine (Ach). Endothelium-intact aortic rings were treated with A-7 antibody ( 1 and $5 \mu \mathrm{g} / \mathrm{ml})$ or $\operatorname{IgG} 2 \alpha(5 \mu \mathrm{g} / \mathrm{ml})$ for 60 min followed by stimulation of norepinephrine $(\mathrm{NE} ; 0.1 \mu \mathrm{M})$ and cumulative treatment with $\mathrm{ACh}$ at the indicated concentrations. A. Representative recording chart images show changes in ACh-elicited relaxation induced by treatment with A-7 antibody. B. Statistical graph obtained from panel $\mathrm{A}$; the magnitude of NE $(0.1 \mu \mathrm{M})$-induced contractile response before treatment with ACh was expressed as $100 \%(n=4)$. Data was statistically analyzed by two-way repeated-measures ANOVA with Tukey's post-hoc test $(\mathrm{F}(4,18)=9.171$, $p=0.0003$, interaction; $\mathrm{F}(2,9)=10.51$, $p=0.0044$, group; $\mathrm{F}(2,18)=243.9, p<0.0001$, concentration $(\mathrm{ACh})) .{ }^{*}$ significant difference compared to ACh-stimulated states in the presence of $\operatorname{IgG} 2 \alpha(p<0.05)$. 
CA, USA). Statistical evaluation of data was performed with a Student's $t$-test (Figs. 2C and 3B) for comparisons between pairs of groups and by a one-way ANOVA (Figs. 4B and 5B) or a two-way repeated-measures ANOVA (Figs. 1C, 2A,B and 3A) followed by a Tukey's post-hoc test for multiple group comparison. The value $p<0.05$ was considered statistically significant.

\section{Results}

\section{Effect of A-7 antibody on endothelium-dependent} vasorelaxation

In a previous study, we generated 22 monoclonal antibodies that regulated the activities of vascular system and identified a vasoactive antibody (Won et al. 2013). To further investigate another monoclonal antibody associated with vascular function, we tested the effects of antibodies with specific reactivity to HUVECs other than the antibody (C7) with vascular reactivity, which is one of the seven antibodies exhibiting more than $80 \%$ specific reactivity to HUVECs in a previous study. Among the different antibodies, A-7 displayed $45.9 \%$ specific reactivity to HUVEC as reported previously (Won et al. 2013) and affected vascular reactivity as shown in Figure 1. Treatment of ACh (0.01-1 $\mu \mathrm{M})$ elicited concentration- dependent inhibition of $\mathrm{NE}(0.1 \mu \mathrm{M})$-induced contraction in endothelium-intact aortic ring isolated from rats, with a maximum inhibition at $1 \mu \mathrm{M}$ of ACh (Figure $1 ; n=4$ ). Treatment with A-7 antibody at a concentration of $5 \mu \mathrm{g} /$ $\mathrm{ml}$, but not at a concentration of $1 \mu \mathrm{g} / \mathrm{ml}$, inhibited the ACh-induced suppression of NE $(0.1 \mu \mathrm{M})$-stimulated contractile response in the aortic ring. On the other hand, the ACh-induced inhibitory response of NE-stimulated contraction did not differ between groups treated with and without IgG2a (Figure 1).

\section{Effect of A-7 antibody on vasorelaxant- or vasoconstrictor- -induced reactivity in endothelium-intact aorta}

To confirm whether A-7 antibody inhibits only the AChinduced response, the effect of A-7 antibody was also tested against histamine-induced relaxation in endothelium-intact aortic rings. Treatment with histamine at a concentration range of 1 to $100 \mu \mathrm{M}$ attenuated the contractile response to $\mathrm{NE}(0.1 \mu \mathrm{M})$ in the endothelium-intact aortic rings in a concentration-dependent manner. However, this histamine-inhibited response was not affected by treatment with $5 \mu \mathrm{g} / \mathrm{ml}$ of A-7 antibody (Figure $2 \mathrm{~A} ; n=5$ ).

To determine the effect of A-7 antibody on vasoreactivity by endothelium-independent vasodilator, we induced endothelium-independent vasodilator SNP-dependent effect against NE-induced precontraction in aortic ring.
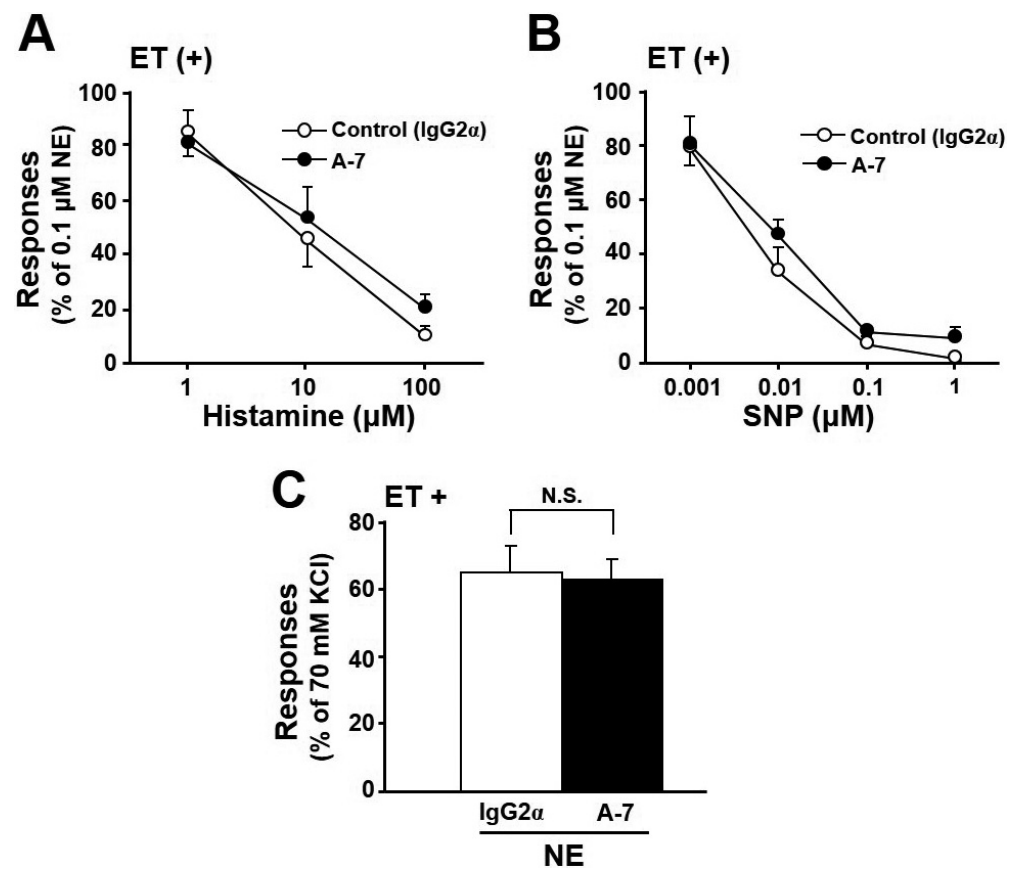

Figure 2. Effects of A-7 antibody on vascular reactivity in endothelium-intact aorta. $\mathbf{A}$ and $\mathbf{B}$. Effects of A-7 antibody on vascular relaxation in endothelium-intact aorta. After treatment with A-7 antibody $(5 \mu \mathrm{g} / \mathrm{ml})$ or IgG2 $\alpha(5 \mu \mathrm{g} / \mathrm{ml})$ for 60 min, endothelium-intact ET (+) aortic rings were stimulated with norepinephrine $(\mathrm{NE} ; 0.1 \mu \mathrm{M})$ and cumulatively treated with histamine $(\mathrm{A} ; n=5)$ or sodium nitroprusside (SNP) $(\mathrm{B} ; n=4)$. The magnitude of NE $(0.1 \mu \mathrm{M})$-induced contraction before treatment with histamine (A) or SNP (B) was considered as $100 \%$. Data was statistically analyzed by two-way repeated-measures ANOVA $[(\mathrm{A}: \mathrm{F}(2,14)=0.9341, p=0.4161$, interaction; $\mathrm{F}(1,6)=0.2114, p=0.6596$, group; $\mathrm{F}(3,18)=67.61$, $p<0.0001$, concentration) (B: $\mathrm{F}(3,18)=0.3744$, $p=0.7725$, interaction; $\mathrm{F}(1,6)=1.360, p=0.2879$, group; $\mathrm{F}(3,18)=72.48, p<0.0001$, concentration)]. C. Effect of A-7 antibody on NE-stimulated contraction of aortic rings. Endothelium-intact (ET $(+))$ aortic ring was stimulated with $\mathrm{NE}(0.1 \mu \mathrm{M})$ in the presence or absence of A-7 antibody $(5 \mu \mathrm{g} / \mathrm{ml})$. The magnitude of $70 \mathrm{mM}$ high $\mathrm{K}^{+}$-induced aortic contraction just before initiation of the experiments is expressed as $100 \%(n=7)$. N.S., not significant $(p>0.05$, Student's $t$-test). 

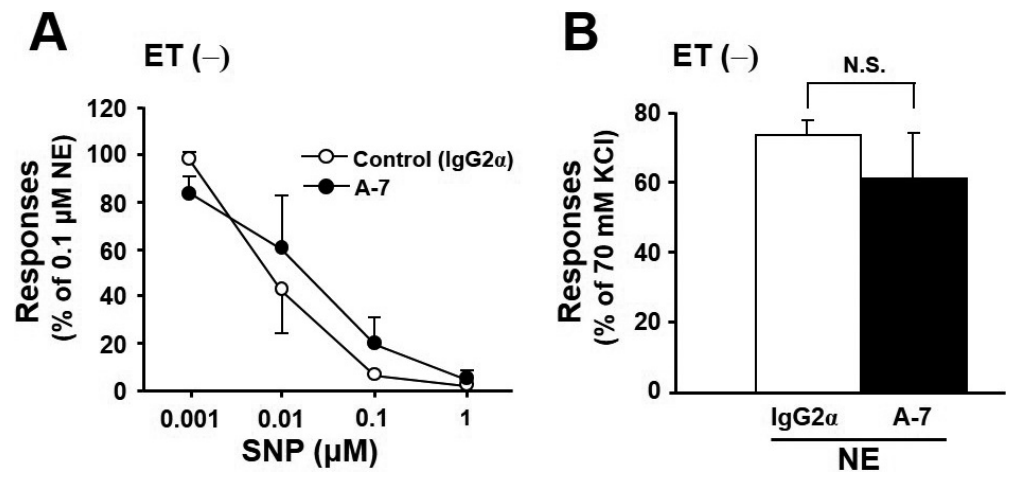

Figure 3. Effects of A-7 antibody on vascular reactivity in aortic smooth muscle. A. Effect of A-7 antibody on sodium nitroprusside (SNP)-induced response of aortic smooth muscle. After treatment with A-7 antibody $(5 \mu \mathrm{g} / \mathrm{ml})$ or IgG2 $\alpha(5 \mu \mathrm{g} / \mathrm{ml})$ for $60 \mathrm{~min}$, endothelium-denuded ET (-) aortic rings were stimulated with norepinephrine (NE; $0.1 \mu \mathrm{M})$ and cumulatively treated with SNP. The magnitude of NE $(0.1 \mu \mathrm{M})$-induced contraction before treatment with SNP was defined as $100 \%$ $(n=4)$. Data was statistically analyzed by twoway repeated-measures ANOVA $(\mathrm{F}(3,18)=1.028$, $p=0.4037$, interaction; $\mathrm{F}(1,6)=0.1725, p=0.6923$,

group; $\mathrm{F}(3,18)=34.86, p<0.0001$, concentration (SNP)). B. Effect of A-7 antibody on NE-induced contraction of aortic smooth muscle. Endothelium-denuded (ET(-)) aortic rings were stimulated with NE $(0.1 \mu \mathrm{M})$ with or without A-7 antibody $(5 \mu \mathrm{g} / \mathrm{ml})$. The magnitude of $70 \mathrm{mM}$ high $\mathrm{K}^{+}$-induced aortic contraction immediately before NE application is expressed as $100 \%(n=4)$. N.S., not significant $(p>0.05$, Student's $t$-test).

Treatment with SNP at a concentration range of 0.001 to $1 \mu \mathrm{M}$ showed concentration-dependent inhibition of the NE-induced contraction in endothelium-intact aortic ring. The SNP-inhibited response of NE-induced contraction did not vary between A-7 antibody $(5 \mu \mathrm{g} / \mathrm{ml})$-treated group and gG2 $\alpha$-treated control (Figure $2 \mathrm{~B} ; n=4$ ). Moreover, treatment with A-7 antibody $(5 \mu \mathrm{g} / \mathrm{ml})$ did not alter NE $(0.1 \mu \mathrm{M})$-induced contraction in endothelium-intact aortic ring (Figure $2 \mathrm{C} ; n=7$ ). The A-7 antibody and IgG2 $\alpha$ control antibodies did not show any effect on the resting tension of aortic ring (data not shown; $n=7$ ). The IgG2 $\alpha$ control antibody also had no effect on the NE-stimulated contractile response (Figure 2).

\section{Effect of A-7 antibody on SNP- or NE-induced vascular smooth muscle reactivity}

To determine the effect of A-7 antibody on endotheliumindependent vascular reactivity in aorta, we also examined the SNP-induced response to NE-triggered contraction in endothelium-denuded aortic ring. As shown in Figure 3A, $\mathrm{NE}(0.1 \mu \mathrm{M})$-stimulated contraction showed concentrationdependent relaxation in the endothelium-denuded aortic ring following treatment with SNP $(0.001-1 \mu \mathrm{M})$. Pretreatment with A-7 antibody $(5 \mu \mathrm{g} / \mathrm{ml})$ did not significantly inhibit the SNP-induced vasorelaxation of NE $(0.1 \mu \mathrm{M})$ stimulated aortic contraction (Figure $3 \mathrm{~A} ; n=4$ ). In addition,
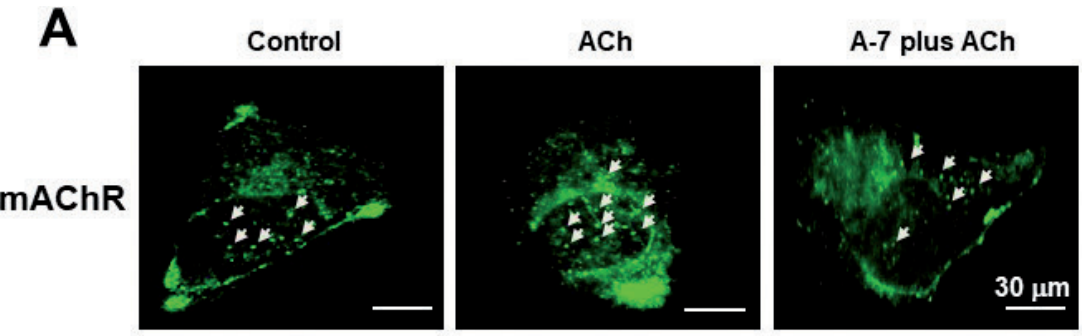

Figure 4. Effect of A-7 antibody on AChR expression on membranes of HUVEC. A. HUVECs were incubated with IgG2a (control) or A-7 antibody $(5 \mu \mathrm{g} / \mathrm{ml})$ for $60 \mathrm{~min}$ and were treated with or without acetylcholine (ACh; $1 \mu \mathrm{M})$ for $10 \mathrm{~min}$. HUVECs were stained with anti-muscarinic M3 AChR (mAChR) antibody and visualized using Alexa Fluor

B

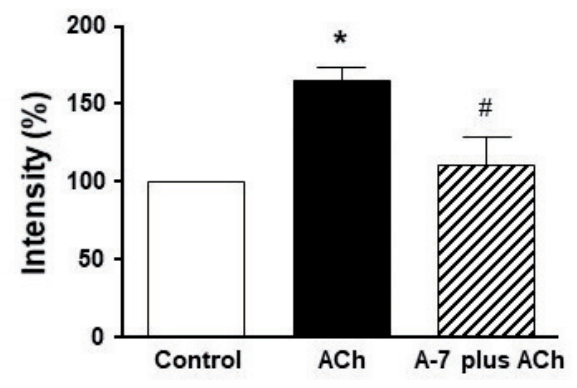
488-conjugated secondary antibody $(n=4)$. The immunostained cells were observed using fluorescence microscopy. Green spots (arrows): mAChR positive responses. Scale bar: $30 \mu \mathrm{m}$. B. Statistical graph obtained from panel A. AChR expression in IgG2a-treated cells was considered as $100 \%$. The difference between treatment conditions was statistically determined by a one-way ANOVA with Tukey's post-hoc test $(\mathrm{F}(2,9)=8.881, p=0.0074) .{ }^{*}$ significant difference compared to the IgG2 $\alpha$ treated $(p<0.05) ;{ }^{\#}$ significant difference compared to the ACh-stimulated states in the absence of A-7 antibody control $(p<0.05)$. (See online version for color figure.) 
treatment with A-7 antibody $(5 \mu \mathrm{g} / \mathrm{ml})$ did not alter NE $(0.1$ $\mu \mathrm{M})$-induced contractions in endothelium-denuded aorta (Figure 3B; $n=4$ ). A-7 and IgG $2 \alpha$ antibodies showed no effect on the resting tension in aortic ring (data not shown; $n=4)$ and IgG2 $\alpha$ also did not affect the NE-induced contraction (Figure 3).

\section{Effect of A-7 treatment on AChR expression on HUVEC membrane}

Based on the results of ACh-induced vasorelaxation of A-7 mentioned above, we determined the correlation between A-7 and AChR expression on the endothelial cellular membrane to elucidate the role of A-7 in ACh-induced endothelial cell activity. As shown in Figure 4, an immunofluorescence staining showed that treatment of HUVECs with ACh $(1 \mu \mathrm{M})$ significantly increased the level of AChR expression and this increase was inhibited by pretreatment with A-7 antibody $(5 \mu \mathrm{g} / \mathrm{ml})(n=4)$.

In addition, the effect of A-7 antibody on AChR expression in HUVECs was confirmed using immunoblotting technique. Similar to the results of immunofluorescence staining, treatment of HUVECs with A-7 antibody (5 $\mu \mathrm{g}$ / ml) significantly reduced the AChR expression level that

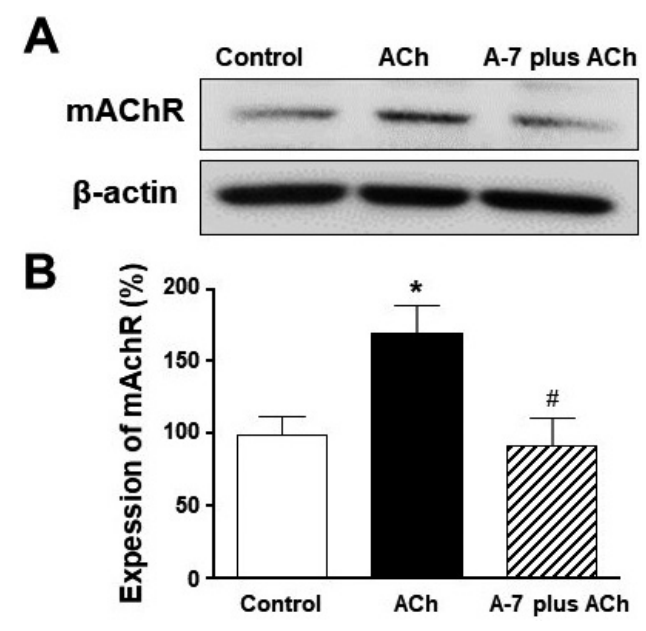

Figure 5. Effect of A-7 antibody on AChR expression in HUVEC. A. HUVECs were incubated with IgG2 $\alpha$ (control) or A-7 antibody $(5 \mu \mathrm{g} / \mathrm{ml})$ for $60 \mathrm{~min}$ and were treated with or without acetylcholine $(\mathrm{ACh} ; 1 \mu \mathrm{M})$ for $10 \mathrm{~min}$. The expression level of AChR in HUVECs was examined by immunoblotting using anti-muscarinic M3 AChR (mAChR) antibody. B. Statistical results obtained from panel A. AChR expression in IgG2a-treated cells was expressed as $100 \%(n=4)$. The difference between treatment conditions was statistically determined by one-way ANOVA analysis with Tukey's post-hoc test $(\mathrm{F}(2,9)=6.544, p=0.0176){ }^{*}$ significant difference compared to the IgG2 $\alpha$-treated control $(p<0.05)$; ${ }^{*}$ significant difference compared to the ACh-stimulated states in the absence of A-7 antibody $(p<0.05)$. was increased in HUVECs by treatment of ACh $(1 \mu \mathrm{M})$ (Figure $5 ; n=4$ ).

\section{Discussion}

In the present study, we found that A-7, one of the monoclonal antibodies induced by injection of HUVECs, statistically significantly inhibited ACh-induced vasorelaxation in endothelium-intact aorta from rats, indicating that A-7 antibody may have an inhibitory activity on ACh-induced vasorelaxation. However, the vascular response induced by A-7 at concentrations higher than $5 \mu \mathrm{g} / \mathrm{ml}$ may need to be investigated in order to more clarify correlation between A-7 and ACh-induced response. Furthermore, in our previous study, a functional monoclonal antibody was detected among antibodies directed against HUVECs (Won et al. 2013). ACh evokes vascular SMC relaxation mediated by signals triggered by the AChR activation in the membrane of ECs (Moncada et al. 1991). Signals induced by AChR activation participate in NO generation contributing to guanylate cyclase activation and cyclic guanosine monophosphate elevation, resulting in vascular SMC relaxation (Jaffe 1985). Therefore, these findings demonstrate that A-7 antibody may be a potential functional protein expressed in ECs associated with EC-dependent relaxation in response to $\mathrm{ACh}$.

Vascular ECs that serve as a barrier between blood and tissue contribute to the maintenance of vascular tone by various substances regulating vascular reactivity (Moncada et al. 1991). NO is induced in ECs by stimuli including histamine as well as ACh in vascular system in a receptordependent manner and is diffused into SMCs (Köhler and Milstein 1975). In the present study, the A-7 antibody showed a very weak inhibitory effect on histamine-induced endothelium-dependent vasorelaxation, which was not statistically significant, implying that it may not significantly affect endothelium-dependent vasorelaxation via histamine-linked signaling. Moreover, the A-7 antibody controlled ACh-induced endothelium-dependent vasorelaxation and attenuated ACh-increased $\mathrm{mAChR}$ induction as shown in immunocytochemistry and immunoblot results. Therefore, it is assumed that the A-7 antibody may participate in mAChR-, but not in histamine receptor-, mediated responses. NE stimulates the activation of adrenoceptors on the plasma membranes of both ECs and SMCs (Endemann and Schiffrin 2004). The activation of adrenoceptors in ECs promotes NO production, leading to smooth muscle relaxation, and induces phospholipase $\mathrm{C}$ activation and $\mathrm{Ca}^{2+}$ influx in SMCs, resulting in SMC contraction (Endemann and Schiffrin 2004). The present study demonstrated that the A-7 antibody did not significantly affect the NE-stimulated contractile response in endothelium-intact or-denuded 
aorta, indicating that A-7 antibody was not associated with adrenoceptor-associated vascular relaxation and contraction. Moreover, A-7 antibody had a statistically non-significant slight inhibitory effect on the vascular response induced by the endothelium-independent NO donor SNP in endothelium-intact and -denuded condition, implying that A-7 antibody may not exert a significant effect on the direct NO generation-induced vascular response. Therefore, these results suggest that A-7 may play a role in signal transduction responses, especially NO generation, triggered by the activation of mAChR in vascular system.

It is well known that mAChRs distributed throughout the human body are classified into five subtypes $\mathrm{m} 1, \mathrm{~m} 2$, m3, m4, and m5AchR (Eglen 2012; Kruse et al. 2014). Activated mAChRs control physiological responses such as heart rate, smooth muscle contraction, glandular secretion and multiple activities in the central nervous system (Eglen 2012). Recently, it was reported that mAChRs play an important role in a variety of cellular functions including brain development (Lebois et al. 2018). Moreover, abnormal $\mathrm{mAChR}$ receptors have been implicated in diseases such as Alzheimer, Parkinson's, and schizophrenia (Wess et al. 2007; Kruse et al. 2014). The m3AchR is located in vascular and gastric SMCs, and in salivary glands (Wess et al. 2007; Tobin et al. 2009). Therefore, the monoclonal antibodies generated by the injection of cells can be considered as a unique therapeutic response clinically.

In summary, we demonstrated that monoclonal A-7 antibody generated by the injection of HUVECs inhibited endothelium-dependent vasorelaxation in response to $\mathrm{ACh}$ but not to histamine. The A-7 antibody did not affect NEinduced contraction in endothelium-intact and -denuded aorta. Moreover, the immunocytochemical and immunoblotting analysis revealed that ACh-increased $\mathrm{mAChR}$ expression was attenuated by treatment with A-7 antibody in HUVECs. These findings indicate that the A-7 antibody has an inhibitory effect on endothelium-dependent vasorelaxation in response to $\mathrm{ACh}$, probably at least partially resulting from the downregulation of $\mathrm{mACh}$ receptor expression. Therefore, monoclonal A-7 antibody may be a valuable molecule to elucidate or better understand the potential functional mechanism linked to ACh-receptor-mediated pathway in the vascular system.

Acknowledgements. This research was supported by the Basic Science Research Program through the National Research Foundation of Korea (NRF) funded by the Korean government (NRF2016R1A5A2012284; 2017R1D1A1B03035674) and by a grant of the Korea Health Technology R\&D Project through the Korea Health Industry Development Institute (KHIDI), funded by the Ministry of Health \& Welfare, Republic of Korea (HI15C1540).

Conflicts of interest. The authors declare that they have no conflict of interest.

\section{References}

Boulanger CM, Morrison KJ, Vanhoutte PM (1994): Mediation by M3-muscarinic receptors of both endothelium-dependent contraction and relaxation to acetylcholine in the aorta of the spontaneously hypertensive rat. Br. J. Pharmacol. 112, 519-524 https://doi.org/10.1111/j.1476-5381.1994.tb13104.x

Eglen RM (2012): Overview of muscarinic receptor subtypes. Handb. Exp. Pharmacol. 208, 3-28 https://doi.org/10.1007/978-3-642-23274-9_1

Endemann DH, Schiffrin EL (2004): Endothelial dysfunction. J. Am. Soc. Nephrol. 15, 1983-1992 https://doi.org/10.1097/01.ASN.0000132474.50966.DA

Furchgott RF (1983): Role of the endothelium in responses of vascular smooth muscle. Circ. Res. 53, 557-573 https://doi.org/10.1161/01.RES.53.5.557

Furchgott RF (1999): Endothelium-derived relaxing factor: discovery, early studies, and identification as nitric oxide. Biosci. Rep. 19, 235-251

Gericke A, Sniatecki JJ, Mayer VG, Goloborodko E, Patzak A, Wess J, Pfeiffer N (2011): Role of M1, M3, and M5 muscarinic acetylcholine receptors in cholinergic dilation of small arteries studied with gene-targeted mice. Am. J. Physiol. Heart. Circ. Physiol. 300, H1602-H1608 https://doi.org/10.1152/ajpheart.00982.2010

Hicklin DJ, Witte L, Zhu Z, Liao F, Wu Y, Li Y, Bohlen P (2001): Monoclonal antibody strategies to block angiogenesis. Drug Discov. Today 6, 517-528

https://doi.org/10.1016/S1359-6446(01)01759-7

Jaffe EA (1985): Physiologic functions of normal endothelial cells. Ann. N.Y. Acad. Sci. 454, 279-291 https://doi.org/10.1111/j.1749-6632.1985.tb11868.x

Jaffe EA, Nachman RL, Becker CG, Minick CR (1973): Culture of human endothelial cells derived from umbilical veins. Identification by morphologic and immunologic criteria. J. Clin. Invest. 52, 2745-2756 https://doi.org/10.1172/JCI107470

Josic D, Clifton JG, Kovac S, Hixson DC (2008): Membrane proteins as diagnostic biomarkers and targets for new therapies. Curr. Opin. Mol. Ther. 10, 116-123

Khaddaj Mallat R, Mathew John C, Kendrick DJ, Braun AP (2017): The vascular endothelium: A regulator of arterial tone and interface for the immune system. Crit. Rev. Clin. Lab. Sci. 54, 458-470 https://doi.org/10.1080/10408363.2017.1394267

Köhler G, Milstein C (1975): Continuous cultures of fused cells secreting antibody of predefined specificity. Nature 256, 495-497 https://doi.org/10.1038/256495a0

Kruse AC, Kobilka BK, Gautam D, Sexton PM, Christopoulos A, Wess J (2014): Muscarinic acetylcholine receptors: novel opportunities for drug development. Nat. Rev. Drug Discov. 13, $549-560$ https://doi.org/10.1038/nrd4295

Lebois EP, Thorn C, Edgerton JR, Popiolek M, Xi S (2018): Muscarinic receptor subtype distribution in the central nervous system and relevance to aging and Alzheimer's disease. Neuropharmacology 136, 362-373 https://doi.org/10.1016/j.neuropharm.2017.11.018 
Lee HM, Jeon BH, Won KJ, Lee CK, Park TK, Choi WS, Bae YM, Kim HS, Lee SK, Park SH, et al. (2009): Gene transfer of redox factor-1 inhibits neointimal formation: involvement of plateletderived growth factor- $\beta$ receptor signaling via the inhibition of the reactive oxygen species-mediated Syk pathway. Circ. Res. 104, 219-227 https://doi.org/10.1161/CIRCRESAHA.108.178699

Lee YA, Hahm DH, Kim JY, Sur B, Lee HM, Ryu CJ, Yang HI, Kim KS (2018): Potential therapeutic antibodies targeting specific adiponectin isoforms in rheumatoid arthritis. Arthritis Res. Ther. 20, 245 https://doi.org/10.1186/s13075-018-1736-3

Miraglia S, Godfrey W, Yin AH, Atkins K, Warnke R, Holden JT, Bray RA, Waller EK, Buck DW (1997): A novel five-transmembrane hematopoietic stem cell antigen: isolation, characterization, and molecular cloning. Blood 90, 5013-5021

Moncada S, Palmer RM, Higgs EA (1991): Nitric oxide physiology, pathophysiology, and pharmacology. Pharmacol. Rev. 43, 109-142

Omori K, Kotera J (2007): Overview of PDEs and their regulation. Circ. Res. 100, 309-327 https://doi.org/10.1161/01.RES.0000256354.95791.f1

Pintérová M, Kuneš J, Zicha J (2011): Altered neural and vascular mechanisms in hypertension. Physiol. Res. 60, 381-402

Polanski M, Anderson NL (2007): A list of candidate cancer biomarkers for targeted proteomics. Biomark. Insights 1, 1-48 https://doi.org/10.1177/117727190600100001

Raffetto JD, Calanni F, Mattana P, Khalil RA (2019): Sulodexide promotes arterial relaxation via endothelium-dependent nitric oxide-mediated pathway. Biochem. Pharmacol. 166, 347-356 https://doi.org/10.1016/j.bcp.2019.04.021

Rodrigo GC, Herbert KE (2018): Regulation of vascular function and blood pressure by circadian variation in redox signaling. Free Radic. Biol. Med. 119, 115-120

https://doi.org/10.1016/j.freeradbiomed.2017.10.381

Rucevic M, Hixson D, Josic D (2011): Mammalian plasma membrane proteins as potential biomarkers and drug targets. Electrophoresis 32, 1549-1564 https://doi.org/10.1002/elps.201100212

Tobin G, Giglio D, Lundgren O (2009): Muscarinic receptor subtypes in the alimentary tract. J. Physiol. Pharmacol. 60, 3-21
Versari D, Daghini E, Virdis A, Ghiadoni L, Taddei S (2009): Endothelium-dependent contractions and endothelial dysfunction in human hypertension. Br. J. Pharmacol. 157, 527-536 https://doi.org/10.1111/j.1476-5381.2009.00240.x

Volonté C, D‘Ambrosi N (2009): Membrane compartments and purinergic signalling: the purinome, a complex interplay among ligands, degrading enzymes, receptors and transporters. FEBS J. 276, 318-329 https://doi.org/10.1111/j.1742-4658.2008.06793.x

Wess J, Eglen RM, Gautam D (2007): Muscarinic acetylcholine receptors: mutant mice provide new insights for drug development. Nat. Rev. Drug Discov. 6, 721-733 https://doi.org/10.1038/nrd2379

Wessler I, Kilbinger H, Bittinger F, Unger R, Kirkpatrick CJ (2003): The non-neuronal cholinergic system in humans: expression, function and pathophysiology. Life Sci. 72, 2055-2061 https://doi.org/10.1016/S0024-3205(03)00083-3

Wessler I, Kirkpatrick CJ (2008): Acetylcholine beyond neurons: the non-neuronal cholinergic system in humans. Br. J. Pharmacol. 154, 1558-1571 https://doi.org/10.1038/bjp.2008.185

Won KJ, Lee KP, Kim DK, Jung SH, Lee CK, Lee DH, Yu SY, Park HH, Lee HM, Kim B (2013): Monoclonal antibody against a-actinin 4 from human umbilical vein endothelial cells inhibits endothelium-dependent vasorelaxation. J. Vasc. Res. 50, $210-220$ https://doi.org/10.1159/000350588

Yin AH, Miraglia S, Zanjani ED, Almeida-Porada G, Ogawa M, Leary AG, Olweus J, Kearney J, Buck DW (1997): AC133, a novel marker for human hematopoietic stem and progenitor cells. Blood 90, 5002-5012

Zarghooni S, Wunsch J, Bodenbenner M, Brüggmann D, Grando SA, Schwantes U, Wess J, Kummer W, Lips KS (2007): Expression of muscarinic and nicotinic acetylcholine receptors in the mouse urothelium. Life Sci. 80, 2308-2313 https://doi.org/10.1016/j.lfs.2007.01.046

Received: March 30, 2019

Final version accepted: August 29, 2019

First published online: October 7, 2019 